\title{
Study on the Impact Mechanism of External Mergers and Acquisitions and Internal Productivity of Enterprises on Enterprise Performance
}

\author{
Zhenjing Zhang ${ }^{a}$, Rong Lai ${ }^{b}$ \\ School of Economics, Management and Law, University of South China, Hengyang, China \\ a Gingerzhenjing@163.com, b2452070596@qq.com
}

\begin{abstract}
It has been a hot issue in enterprise economy that how to improve enterprise performance. In this regard, the paper has selected the sample of listed companies in Shanghai Stock Exchange (SSE) and Shenzhen Stock Exchange (SZSE) from 2016 to 2019, and adopted multiple linear regression model to empirically measure the interactive effect of M\&A decision-making and enterprise production efficiency on enterprise performance. The study eventually got the following conclusion. First, in general, the improvement of enterprise production efficiency is more conducive to enterprise performance than M\&A expansion. Second, compared with the traditional manufacturing industry and the emerging Internet industry, the supporting effect of enterprise production efficiency on enterprise performance is more obvious in the Internet industry, but the M\&A measures in both industries show the delayed effect on enterprise performance. Third, with the expansion of enterprise assets, the influence of M\&A decisions and enterprise production efficiency on enterprise performance gradually declines, which indicates that enterprises should adjust their development mode in time according to their own life cycle, and fully cope with the unknown problems and challenges.
\end{abstract}

Keywords: M\&A Decision; Total Factor Productivity; Enterprise Performance; Mechanism Analysis.

\section{Introduction}

In fact, the improvement of enterprise performance is the joint product of external and internal factors. M\&A decisions and production efficiency are respectively the core internal factor and core external factor that affect enterprise performance. Therefore, in recent years, the impact of M\&A and production efficiency on enterprise performance has attracted extensive attention from both domestic and foreign field. Specifically, due to the limited resources like enterprise funds, manpower, etc., the enterprise may need to make the following choices in a short time to maximize the benefits. The question is, whether the money should be spent internally on the introduction of technology to enhance the total factor productivity of the enterprise, or externally on the acquisitions of different companies to achieve access to financial performance.

\section{Literature Review and Research Hypotheses}

Most of the existing literature is about the impact of M\&A decision and enterprise productivity on enterprise performance. There are few studies on the interaction between the two. With respect of the status quo mentioned above, this paper, on the basis of previous studies, is supposed to adopt multiple linear regression model to analyze and compare the influence mechanism of M\&A measures and enterprise production efficiency on enterprise performance in different angles, and further provide reference basis for enterprises to choose improve internal factors or external ones.

\subsection{The Impact Mechanism of M\&A on Firm Performance}

Chen (2016) has taken 424 M\&A events of 366 SSE or SZSE A-share listed enterprises in China as a research sample to conduct empirical analysis. He found that the overall performance of Chinese enterprises after M\&A is significantly lower than the level before M\&A, and M\&A activities damage the value of enterprises on the whole. Meanwhile, Song (2019) pointed out that the impact of direct 
investment on enterprise profitability is not significant on the whole, and the impact is hysteretic and dynamic. Based on this, this paper proposes the following hypothesis.

H1: M\&A measures have a significant negative delayed effect on corporate performance.

More elaborately, in terms of emerging high-tech enterprises, Xia (2020) took listed high-tech enterprises in China from 2011 to 2014 as samples and discovered that technology M\&A of hightech enterprises has a significant positive impact on the economic performance. Apart from whether the enterprise has $M \& A$ in general, the experience of $M \& A$ also has a significant impact on the quality of M\&A, thus further affecting the performance of the enterprise. Zhang (2019) stated that the experience accumulated by enterprises in the process of implementing cross-border M\&A will positively influence its subsequent target selection, negotiation and enterprise integration, thus having a positive impact on performance.

\subsection{The Impact Mechanism of Enterprise Production Efficiency on Enterprise Performance}

Zhu (2017) found that compared with non-technical executives, technical executives affect the hump relationship of corporate performance in the four levels of structural rights, ownership rights, expert rights and reputation rights more significantly. In other words, if technology executives are given appropriate structural rights, and if more technology executives are admitted to the Board of Directors, who will be encouraged and supported to implement innovative projects and invest in research and development, the performance of enterprises will be improved. The growth of total factor productivity mainly comes from technological change and innovation (Zhu, 2021). Accordingly, this paper puts forward the following hypothesis.

$\mathrm{H} 2$ : Enterprise production efficiency has a significant positive promoting effect on enterprise performance.

\subsection{Comparison of the Impact Mechanism of M\&A and Enterprise Production Efficiency on Enterprise Performance}

Pang (2020) studied the relationship among internal control, non-recurring profit\&loss and enterprise performance based on the data and information of A-share listed enterprises in SSE and SZSE from 2012 to 2017. This paper, taking the internal and external factors mentioned above into account, makes a comparative study to analyze the mechanism of M\&A and enterprise production efficiency on enterprise performance. Thus, the following hypothesis is made.

H3: The promotion of enterprise production efficiency by enterprises can promote the development of enterprise performance more than blindly carrying out M\&A measures.

\section{Sample and Study Design}

\subsection{Sample Selection and Data Sources}

This paper selects listed companies of SSE and SZSE from 2016 to 2019 as research samples. The interception period is set at 4 years because the market environment changes rapidly and the life cycle of listed companies is relatively short. Four years is the period for the sustainable development of conventional listed companies.

The data of controlled variables like asset return rate, total factor productivity, whether M\&As occur and so on are all derived from the research series on corporates of CSMAR database. Considering the integrity of the data, some data about special cases has been eliminated, such as the case in which the manager also serves as the chairman of the BoD. This is done to ensure the quantity of total samples and the quality of regression analysis.

\subsection{Variable Definition and Model Construction}

In order to compare the impact mechanism of M\&A measures and production efficiency on enterprise performance, this paper constructs a multiple linear regression model as follows: 
Volume 17 (2022)

$$
\text { ROA }=\beta_{0}+\beta_{1} \text { TFP }+\beta_{2} \text { Merger }+\beta_{3} \text { Industry }+\alpha
$$

Chao et al. (2010) pointed out that although the accounting profit index in the financial indicators is often manipulated, in recent years, due to the government's intensified supervision, the financial data disclosed by listed companies and intermediary agencies are fundamentally real. Different researchers choose different indicators when using financial indicators to measure performance. Some prefer operating income and net profit, etc., while more scholars use ROA to do so (Zhang, 2017). Therefore, the dependent variable in this paper, enterprise performance, is measured by ROA, which is obtained by the accounting formula (net profit after tax/total assets) at the end of the year. Since the improvement of enterprises' total factor productivity is an important micro basis for the rapid growth of China's economy in the past three decades (Zuo, 2017), and the LP method is the result of the improvement of OP method in the measurement of total factor productivity, the independent variable (TFP) of the regression model in this paper is the total factor productivity under the LP method.

Besides, after sorting out the literature, it is found that there are many factors affecting enterprise performance. To control the influence of these factors, this paper has referred to a number of literature studies and controlled the following variables in the regression model: ownership concentration (proportion of equity held by the top 10 shareholders of listed company), enterprise size (natural logarithm of total assets), price-to-book ratio (book-to-market ratio), and debt level (operating leverage and financial leverage). Finally, the paper also controls the industry dummy variable in the regression. See Table 1 for definitions of main variables.

Table 1. Definition of Main Variables

\begin{tabular}{|c|c|c|c|}
\hline Type & Variable & Symbol & Description \\
\hline $\begin{array}{l}\text { dependent } \\
\text { variable }\end{array}$ & $\begin{array}{l}\text { enterprise } \\
\text { performance }\end{array}$ & $R O A$ & asset return rate, net profit after tax/total assets \\
\hline \multirow{2}{*}{$\begin{array}{l}\text { independent } \\
\text { variable }\end{array}$} & $\begin{array}{l}\text { enterprise } \\
\text { productivity }\end{array}$ & TFP & total factor productivity under LP method \\
\hline & M\&A Situation & Merger & $\begin{array}{l}\text { In case of M\&A of listed company, } 1 \text { shall be } \\
\text { taken, otherwise } 0\end{array}$ \\
\hline \multirow{6}{*}{$\begin{array}{l}\text { controlled } \\
\text { variables }\end{array}$} & $\begin{array}{l}\text { ownership } \\
\text { concentration }\end{array}$ & $H E R F$ & $\begin{array}{l}\text { proportion of shares held by the top } 10 \text { shareholders of listed } \\
\text { companies }\end{array}$ \\
\hline & enterprise scale & $A S T$ & natural logarithm of total assets of listed companies \\
\hline & PBR & $H M L$ & $\begin{array}{l}\text { Book-to-market ratio of listed companies, total assets /market } \\
\text { value }\end{array}$ \\
\hline & $\begin{array}{l}\text { operating } \\
\text { leverage }\end{array}$ & $D O L$ & $\begin{array}{c}\text { net profit }+ \text { income tax expense }+ \text { financial expense }+ \\
\text { depreciation of fixed assets, oil\&gas assets, and productive } \\
\text { biological assets }+ \text { amortization of intangible assets }+ \\
\text { amortization of long-term deferred expenses)/(net profit }+ \\
\text { income tax expense + financial expense) }\end{array}$ \\
\hline & $\begin{array}{l}\text { financial } \\
\text { leverage }\end{array}$ & $D F L$ & $\begin{array}{c}\text { (net profit }+ \text { income tax expense+financial expense)/(net } \\
\text { profit }+ \text { income tax expense) }\end{array}$ \\
\hline & Industry & Industry & industry dummy variable \\
\hline
\end{tabular}

\subsection{Descriptive Statistics}

Table 2 is a descriptive statistic for the variables. From the statistical results, the average value of whether the listed companies will conduct M\&As or not is 0.0576 ( 1 is M\&As, 0 is no M\&A), and many companies have never completed M\&As in the four-year period. The minimum value of total factor productivity is 3.319 , the maximum value is 10.47 , and the average value is 7.694 under the LP method, which is basically consistent with the results of the total factor productivity of listed companies measured by the LP method in relevant literature. Thus, there are great differences in the production efficiency of different companies and enterprises. Total factor productivity is the index adopted to measure the production efficiency of enterprises in this paper. The literature studies show 
that the regional difference is a significant factor influencing the total factor productivity. In addition to the influence of geography, individual enterprises and industry characteristics, the institutional environment of different regions (mainly the process of marketization) is also an important reason for such differences (Zuo, 2017). The descriptive statistical results of other variables are close to those of the existing literature, which will not be repeated here.

Table 2. Descriptive Statistics

\begin{tabular}{|c|c|c|c|c|c|}
\hline Variable & Measured Value & Mean Value & $\begin{array}{c}\text { Standard } \\
\text { deviation }\end{array}$ & Minimum Value & Maximum Value \\
\hline$R O A$ & 7,945 & 0.0126 & 0.0167 & -0.0836 & 0.2820 \\
\hline TFP & 7,945 & 7.6940 & 2.0790 & 3.3190 & 10.4700 \\
\hline Merger & 7,956 & 0.0576 & 0.2330 & 0.0000 & 1.0000 \\
\hline$H E R F$ & 7,945 & 57.9900 & 16.4400 & 0.1000 & 101.0000 \\
\hline$A S T$ & 7,945 & 22.2300 & 1.2460 & 18.3500 & 28.2800 \\
\hline$H M L$ & 7,945 & 0.6500 & 0.2590 & 0.0222 & 1.4630 \\
\hline$D O L$ & 7,896 & 1.6680 & 4.1330 & 0.9340 & 316.3000 \\
\hline$D F L$ & 7,869 & 1.3710 & 3.3180 & -81.3400 & 219.0000 \\
\hline
\end{tabular}

\section{Empirical Analysis}

\subsection{Correlation Analysis}

Table 3 shows the results of correlation analysis for the variables involved in the regression model. According to the statistical results, the correlation coefficient between the enterprise production efficiency represented by total factor productivity and the enterprise performance ROA is 0.232 , which shows a strong positive correlation. The correlation coefficient between M\&A and ROA is 0.055 , which is a weak negative correlation. Based on this, it can be predicted that the production efficiency of enterprises has a more obvious promoting effect on the improvement of enterprise performance than the M\&A measures. At the same time, there is a certain correlation between the other controlled variables and the main variables.

Table 3. Correlation Analysis

\begin{tabular}{|c|c|c|c|c|c|c|c|}
\hline Variable & (1) & (2) & (3) & (4) & (5) & (6) & (7) \\
\hline$R O A$ & 1.000 & & & & & & \\
\hline TFP & 0.232 & 1.000 & & & & & \\
\hline Merger & -0.055 & 0.059 & 1.000 & & & & \\
\hline HERF & 0.166 & 0.170 & -0.047 & 1.000 & & & \\
\hline$A S T$ & -0.075 & 0.681 & 0.075 & 0.145 & 1.000 & & \\
\hline$H M L$ & -0.237 & 0.308 & 0.045 & 0.044 & 0.579 & 1.000 & \\
\hline$D O L$ & -0.071 & -0.080 & 0.000 & 0.004 & 0.041 & 0.032 & 1.000 \\
\hline
\end{tabular}

\subsection{Benchmark Regression Results}

Table 4 shows the results of correlation analysis for the variables involved in the regression model. The results in column (1) show that there is a significant positive correlation between enterprise production efficiency and corporate efficiency, while there is a significant negative correlation between enterprise M\&As and corporate efficiency. To ensure the robustness of the regression results, 
the regression coefficient is adjusted at the industry level. In order to avoid the heteroscedasticity, the robustness standard error adjustment is carried out.

From the regression results, it can be seen that production efficiency has a significant positive effect on enterprise performance, while M\&A decision-making shows a significant negative effect. Financial leverage, operating leverage and other controlled variables are not significant, because such variables have little impact on the performance of enterprises at this stage of enterprise development. The information obtained from the model demonstrates that strengthening the production efficiency of enterprises to improve the performance of enterprises is more effective than mergers and acquisitions. Theoretically, M\&A is a main form of capital operation and management. When an enterprise develops to a certain scale and level, it is not strange for it to expand outward and carry out M\&As to expand its own industrial and commercial territory. However, this seems to be contrary to the expected results, and there are two main reasons accounting for it. First, a large part of M\&A can be defined as blind expansion, which makes the company to present a chaotic scenario. Second, the quality of M\&As is affected by the nature of the industry itself, and the expansion of enterprises in some industries may not have a positive impact.

On the other hand, production efficiency, no matter in terms of the significance, or the size of the coefficient, can display its obvious improvement of enterprise performance. This is an evidence for an important law: total factor productivity refers to the efficiency of production activities in a certain period of time, and is a productivity index to measure the unit total input and total output. Generally speaking, total factor productivity refers to the difference between output and input, but because this difference can hardly be attributed to a specific production factor, it is collectively referred to as "total factor". The main source of TFP growth is technological change and innovation (Zhu, 2021). The introduction of cash technology and the innovation of existing technology can further save cost and expand production, which is bound to create a positive impact on the production efficiency of enterprises.

Table 4. Benchmark Regression Results

\begin{tabular}{|c|c|c|c|}
\hline Variable & ROA & Variable & ROA \\
\hline \multirow{2}{*}{$T F P$} & $0.004^{* * *}$ & \multirow{2}{*}{$H M L$} & $-0.013^{* * *}$ \\
\hline & $(<0.001)$ & & $(<0.001)$ \\
\hline \multirow{2}{*}{ Merger } & $-0.002^{* * *}$ & \multirow{2}{*}{$D O L$} & $-1 \mathrm{E}-04$ \\
\hline & $(<0.001)$ & & $(<0.001)$ \\
\hline \multirow{2}{*}{$H E R F$} & $1.21 \mathrm{E}-04^{* * *}$ & \multirow{2}{*}{$D F L$} & $-5 \mathrm{E}-05$ \\
\hline & $(<0.001)$ & & $(<0.001)$ \\
\hline \multirow{2}{*}{$A S T$} & $-0.004^{* * *}$ & Industry & Control \\
\hline & $(<0.001)$ & robust standard error & Yes \\
\hline$N$ & 7810 & $R^{2}$ & 0.266 \\
\hline
\end{tabular}

Note: Standard errors are in brackets; *, **, *** represent significant at 10\%, 5\%, and $1 \%$ levels respectively.

\subsection{Robustness Test}

\subsubsection{Substitution Variable Test}

First, there are different measurement methods of enterprise performance, so this paper also selects indictors including earnings per share (EPS) and return on equity(ROE) to re-regress, and finds that the conclusion is consistent. Second, change the independent variable measurement method. In terms of M\&As, this paper adopts " 1 for M\&A and 0 for no M\&A" to measure the situation quantitatively. However, this fails to take into account the influence of frequency, which may lead to the noise in variables. Therefore, this paper changes the number of M\&As (NUM) between 2016 and 2019 to carry out a stable test. As for enterprise production efficiency, the total factor productivity under LP is chosen. For the measurement of total factor productivity, there are many different methods in the existing literature. In the same way, this paper uses total factor productivity (TFP) under OP method and TFP under conventional method to test the robustness of the hypothesis. 
Table 5. Robustness Test: Measure by Variable

\begin{tabular}{|c|c|c|c|c|c|}
\hline Variable & (1)ROE & (2)EPS & (3)ROA & (4)ROA & (5)ROA \\
\hline \multirow{2}{*}{ rate } & & & $0.004^{* * *}$ & & \\
\hline & & & $(<0.001)$ & & \\
\hline \multirow{2}{*}{$T F P$} & $0.008^{* * *}$ & $0.029^{* * *}$ & & & $0.004^{* * *}$ \\
\hline & $(0.001)$ & $(0.002)$ & & & $(<0.001)$ \\
\hline \multirow{2}{*}{$T F P_{-} 1$} & & & & $0.004^{* * *}$ & \\
\hline & & & & $(<0.001)$ & \\
\hline \multirow{2}{*}{ Merger } & $9.04 \mathrm{E}-04$ & $-0.019^{*}$ & $-0.003^{* * *}$ & $-0.003^{*}$ & \\
\hline & $(0.004)$ & $(0.011)$ & $(<0.001)$ & $(<0.001)$ & \\
\hline \multirow{2}{*}{$N U M$} & & & & & $-5.92 \mathrm{E}-04^{* *}$ \\
\hline & & & & & $(<0.001)$ \\
\hline \multirow{2}{*}{$D F L$} & $-2 \mathrm{E}-04$ & $-0.002^{*}$ & $-5.04 \mathrm{E}-05$ & $-4.43 \mathrm{E}-05$ & $-0.002^{*}$ \\
\hline & $(<0.001)$ & $(<0.001)$ & $(<0.001)$ & $(<0.001)$ & $(<0.001)$ \\
\hline \multirow{2}{*}{$H E R F$} & $1.09 \mathrm{E}-04$ & $0.001^{* * *}$ & $1.21 \mathrm{E}-04^{* * *}$ & $1.22 \mathrm{E}-04^{* * *}$ & $1.22 \mathrm{E}-04^{* * *}$ \\
\hline & $(<0.001)$ & $(<0.001)$ & $(<0.001)$ & $(<0.001)$ & $(<0.001)$ \\
\hline \multirow{2}{*}{$A S T$} & $-0.007^{* * *}$ & $-0.018^{*}$ & $-0.004^{*}$ & $-0.004^{* * *}$ & $-0.004^{* * *}$ \\
\hline & $(0.002)$ & $(0.010)$ & $(<0.001)$ & $(<0.001)$ & $(<0.001)$ \\
\hline \multirow{2}{*}{$H M L$} & -0.005 & $-0.162^{* * *}$ & $-0.123^{* * *}$ & $-0.013^{* * *}$ & $-0.013^{* * *}$ \\
\hline & $(0.007)$ & $(0.031)$ & $(<0.001)$ & $(<0.001)$ & $(<0.001)$ \\
\hline \multirow{2}{*}{$D O L$} & 7.64E-06 & $-0.002^{*}$ & $-1.13 \mathrm{E}-04$ & $-1.12 \mathrm{E}-04$ & $-1.09 \mathrm{E}-04$ \\
\hline & $(<0.001)$ & $(0.001)$ & $(<0.001)$ & $(<0.001)$ & $(<0.001)$ \\
\hline Industry & Control & Control & Control & Control & Control \\
\hline robust standard error & Yes & Yes & Yes & Yes & Yes \\
\hline$N$ & 7806 & 7809 & 7810 & 7810 & 7810 \\
\hline$F$ & $18.35^{* * *}$ & $33.25^{* * *}$ & $33.59^{* * *}$ & $32.90^{* * *}$ & $33.11^{* * *}$ \\
\hline$R^{2}$ & 0.0240 & 0.2660 & 0.2659 & 0.2663 & 0.2652 \\
\hline
\end{tabular}

Note: Standard errors are in brackets; $*, * *, * * *$ represent significant at $10 \%, 5 \%, 1 \%$ levels respectively.

The results show that when the parameters of dependent variables and independent variables mentioned above are changed, the evaluation methods and indicators adopted in this paper still have a more significant role in promoting enterprise production efficiency than M\&A. The evaluation results remain a relatively consistent and stable, and there is no significant change in the regression results. Therefore, the robustness of the model is good, and the benchmark regression results are more accurate.

\subsubsection{Endogenous Test}

Although the above analysis has found the correlation among M\&A measures, enterprise production efficiency and enterprise performance, it is still necessary to further identify the internal causal relationship. Table 6 shows the regression results using the instrumental variable method. A good instrumental variable needs to meet two requirement: sound externality and correlation. This 
paper uses the lag period of M\&A times and the lag period of total factor productivity under LP method as the tool variables of enterprise performance. In order to verify whether the tool variables constructed in this way satisfy the requirement of exogenous hypothesis, this paper directly brings the tool variables into the regression model. It is found that the tool variables TFP_1 and Merger_1 have no direct relationship with the M\&A performance, so they are in consistency with the exogenous hypothesis. To reduce the estimation bias caused by the nonlinear model setup and to obtain unbiased parameter estimates, this paper uses a two-stage linear instrumental variable regression model.

After removing endogeneity, it can be seen that the size and direction of the influence coefficient of independent variables on dependent variables in the regression results remain unchanged, and the influence of enterprise production efficiency on enterprise performance is between 0.0036 and 0.004 . Therefore, the endogeneity influences very little, and the regression results of the model are robust and reliable.

Table 6. Robustness Test: Endogenous Test

\begin{tabular}{|c|c|c|c|}
\hline \multirow{2}{*}{ Variable } & \multicolumn{2}{|c|}{ Phase I } & Phase II \\
\hline \multirow{2}{*}{ TFP } & TFP & Merger & $R O A$ \\
\hline \multirow{2}{*}{ Merger } & & & $0.004^{* * *}$ \\
\cline { 2 - 4 } & & & $(<0.001)$ \\
\hline \multirow{2}{*}{ TFP_1 } & & & $-0.007^{*}$ \\
\hline \multirow{2}{*}{ Merger_l } & & & $(0.002)$ \\
\hline Industry & $\left(0.69^{* * *}\right.$ & $-7.51 \mathrm{E}-04$ & \\
\hline robust standard error & -0.33 & $(0.002)$ & \\
\hline controlled variables & $(0.07)$ & $0.289^{* * *}$ & $(0.03)$ \\
\hline$N$ & Control & Control & Control \\
\hline$F$ & Yentrol & Yes & Yes \\
\hline$R^{2}$ & 5853 & 5853 & 5853 \\
\hline Adjusted $R^{2}$ & $419.81^{* * *}$ & $5.1^{* * *}$ & \\
\hline & 0.7655 & 0.1249 & 0.3434 \\
\hline
\end{tabular}

Note: Standard errors are in brackets; $* * *, * * *$ represent significant at $10 \%, 5 \%$, and $1 \%$ levels respectively.

\section{Heterogeneity Analysis}

From the above analysis, it is clear that the effect of M\&A and production of listed companies on corporate performance may vary depending on industry characteristics and institutional environment (mainly marketization process). In this regard, this paper will further conduct discussion in groups in order to explore the impact mechanism of M\&A measures and enterprise production efficiency on enterprise performance under different conditions.

\subsection{Industry Group Test}

This paper mainly analyzes the regression results of listed companies in manufacturing industry and Internet field. This is because these two types of industries are the most representative and largescale industries in today's society. The obvious difference between the two industries is also conducive to the mechanism comparison between M\&A measures and enterprise production efficiency on enterprise performance. As shown in Table 7, enterprise productivity has a significant positive effect on enterprise performance, both for the traditional manufacturing industry and the emerging Internet industry. M\&A still plays a negative role. The horizontal comparison can further 
verify that compared with the traditional manufacturing industry, the improvement of enterprise production efficiency can better the enterprise performance of the Internet industry.

Table 7. Heterogeneity Test: Grouping by Industry

\begin{tabular}{|c|c|c|c|c|c|}
\hline & $\boldsymbol{R O A}$ & $\boldsymbol{R O A}$ & $\boldsymbol{R O A}$ & Manufacturing & Internet industry \\
\hline MFP & $\begin{array}{c}0.004^{* * *} \\
(<0.001)\end{array}$ & $\begin{array}{c}0.005^{* * *} \\
(<0.001)\end{array}$ & $A S T$ & $\begin{array}{c}-0.004^{* * *} \\
(<0.001)\end{array}$ & $\begin{array}{c}-0.010^{* * *} \\
(0.002)\end{array}$ \\
\hline Merger & $\begin{array}{c}-0.003^{* * *} \\
(<0.001)\end{array}$ & $\begin{array}{c}-0.005 \\
(0.006)\end{array}$ & $H M L$ & $\begin{array}{c}-0.013^{* * *} \\
(0.001)\end{array}$ & $\begin{array}{c}-0.004 \\
(0.005)\end{array}$ \\
\hline DFL & $\begin{array}{c}-2.78 \mathrm{E}-05 \\
(<0.001)\end{array}$ & $\begin{array}{c}5.94 \mathrm{E}-04 \\
(<0.002)\end{array}$ & $D O L$ & $\begin{array}{c}-0.001^{* * *} \\
(0.001)\end{array}$ & $\begin{array}{c}-8.39 \mathrm{E}-04 \\
(<0.001)\end{array}$ \\
\hline HERF & $\begin{array}{c}1.40 \mathrm{E}-04^{* * *} \\
(<0.001)\end{array}$ & $\begin{array}{c}1.63 \mathrm{E}-04^{* * *} \\
(<0.001)\end{array}$ & $N$ & 4890 & 489 \\
\hline $\begin{array}{c}\text { robust standard } \\
\text { error }\end{array}$ & Control & Control & $R^{2}$ & 0.2817 & 0.2087 \\
\hline Industry & Control & Control & & & \\
\hline
\end{tabular}

Note: Standard errors are in brackets; ${ }^{*}, * *, * * *$ represent significant at $10 \%, 5 \%$, and $1 \%$ levels respectively.

\subsection{Asset Scale Tests by Classification}

Table 8. Heterogeneity Test: Quartile Grouping By Asset Size

\begin{tabular}{|c|c|c|c|c|}
\hline Variable & (1)ROA & (2)ROA & (3)ROA & (4)ROA \\
\hline & Less than $25 \%$ quantile & $25 \%-50 \%$ & $50 \%-75 \%$ & Greater than $75 \%$ quantile \\
\hline TFP & $\begin{array}{l}0.007^{* * *} \\
(<0.001)\end{array}$ & $\begin{array}{l}0.004^{* * *} \\
(<0.001)\end{array}$ & $\begin{array}{l}0.003^{* * *} \\
(<0.001)\end{array}$ & $\begin{array}{l}0.002^{* * *} \\
(<0.001)\end{array}$ \\
\hline Merger & $\begin{array}{c}-0.006^{* * *} \\
(0.002)\end{array}$ & $\begin{array}{l}-0.004^{* *} \\
(0.001)\end{array}$ & $\begin{array}{l}-0.001 \\
(0.001)\end{array}$ & $\begin{array}{c}-5.07 \mathrm{E}-04 \\
(<0.001)\end{array}$ \\
\hline$D F L$ & $\begin{array}{l}-0.001^{* * *} \\
(<0.001)\end{array}$ & $\begin{array}{l}1.00 \mathrm{E}-05 \\
(<0.001)\end{array}$ & $\begin{array}{l}3.48 \mathrm{E}-05 \\
(<0.001)\end{array}$ & $\begin{array}{c}1.97 \mathrm{E}-04^{*} \\
(<0.001)\end{array}$ \\
\hline$H E R F$ & $\begin{array}{c}2.37 \mathrm{E}-04^{* * *} \\
(<0.001)\end{array}$ & $\begin{array}{c}9.26 \mathrm{E}-05^{* * *} \\
(<0.001)\end{array}$ & $\begin{array}{c}5.48 \mathrm{E}-05^{* * *} \\
(<0.001)\end{array}$ & $\begin{array}{c}3.16 \mathrm{E}-05^{*} \\
(<0.001)\end{array}$ \\
\hline$A S T$ & $\begin{array}{c}-0.009^{* * *} \\
(0.001)\end{array}$ & $\begin{array}{c}-0.009^{* * *} \\
(0.002)\end{array}$ & $\begin{array}{l}-0.003^{* *} \\
(0.001)\end{array}$ & $\begin{array}{l}2.34 \mathrm{E}-04 \\
(<0.001)\end{array}$ \\
\hline$H M L$ & $\begin{array}{c}-3.28 \mathrm{E}-04 \\
(0.002)\end{array}$ & $\begin{array}{c}-0.006^{* * *} \\
(0.001)\end{array}$ & $\begin{array}{c}-0.014^{* * *} \\
(0.002)\end{array}$ & $\begin{array}{c}-0.023^{* * *} \\
(0.002)\end{array}$ \\
\hline$D O L$ & $\begin{array}{c}-8.41 \mathrm{E}-04^{* * *} \\
(0.001)\end{array}$ & $\begin{array}{c}-6.70 \mathrm{E}-04^{*} \\
(<0.001)\end{array}$ & $\begin{array}{c}-6.38 \mathrm{E}-04^{*} \\
(<0.001)\end{array}$ & $\begin{array}{c}-8.52 \mathrm{E}-04^{* *} \\
(<0.001)\end{array}$ \\
\hline Industry & Control & Control & Control & Control \\
\hline robust standard error & Control & Control & Control & Control \\
\hline$N$ & 1941 & 1960 & 1957 & 1871 \\
\hline$R^{2}$ & 0.2790 & 0.3497 & 0.3561 & 0.4384 \\
\hline
\end{tabular}

Note: Standard errors are in brackets; *, **, *** represent significant at $10 \%, 5 \%$, and $1 \%$ levels respectively.

In this paper, with partial reference to the practice of Hsien and Zheng (2015), the sample of listed companies is classified by quartile at the industry level according to the size of total assets. The regression results are shown in Table 8 below. The results tell that for any asset size listed enterprises, 
enterprise production efficiency has a significant positive role in promoting enterprise performance. However, the M\&A situation has the most significant impact on the listed companies with asset size less than $50 \%$ quantile, and the effect is still negative. From horizontal comparison, it can be further observed that with the expansion of enterprise asset scale, the significant positive influence of enterprise production efficiency on enterprise performance is gradually decreasing, while the negative influence of external M\&As on enterprise is also gradually decreasing.

\section{Conclusion}

Based on data from companies listed on the SSE and SZSE during the period 2016-2019, this paper is the first to measure the effect on corporate performance for both sides of the M\&A initiative and corporate productivity in an integrated manner. The main conclusions are as follows:

First, through benchmark analysis, it can be seen that the improvement of enterprise production efficiency is more conducive to enterprise performance than M\&A expansion. This is due to the fact that there is a general blind outward M\&A situation among listed companies. A comprehensive analysis of theory and literature shows that blind M\&A, as a kind of irrational investment behavior, demonstrate the lack of consideration in two aspects. On the one hand, managers fail to conduct multilevel analysis on the selection of M\&A targets, and on the other hand, they fail to fully consider how to integrate the acquired company into the parent company more quickly and better during the M\&A process. This is very likely to lead to internal disorder and inefficient management, resulting in the structural problem of $" 1+1<2$ " presented in the regression results of this paper.

Second, the industry heterogeneity analysis shows that the sample grouping of listed companies in traditional manufacturing and emerging Internet industries is regressed. The results tell that compared with the traditional manufacturing industry, the supporting effect of enterprise production efficiency on enterprise performance is more obvious in the Internet industry. However, M\&A measures have shown negative lagging effects on enterprise performance in both industries. Companies in the Internet industry can pay more attention to the methods of using advanced technologies to maximize the efficiency of their resources and the production of their products or services. At the same time, both industries need to make prudent merger-related decisions. In the process of mergers and acquisitions, companies need to integrate internal and external aspects. It is necessary not only to strengthen the inner system but also to focus on the selection of external targets (Xia, 2020). The enterprise should try to avoid blind M\&As, which will drag down corporate performance.

Third, the analysis of asset size heterogeneity shows that the significant positive influence of enterprise productivity on performance decreases as enterprise asset size increases, and the negative impact of M\&A on firms also decreases. The impact of both M\&A and enterprise productivity on firm performance is in a state of gradual decline. This demonstrates that the improvement in corporate performance of enterprises with larger assets is not only limited by M\&As and corporate productivity, but is often influenced by a wider range of factors. Medium and lower sized companies can focus on improving their productivity and promote technological innovation to improve their performance faster and better.

\section{References}

[1] Zhu, N., et al. Structural Total Factor Productivity Growth in China's Banking Sector [J]. Journal of Financial Research, 2021(7):1-18.

[2] Liu, S.C., et al. Can Corporate Digital Transformation Promote Input-Output Efficiency[J], Journal of Management World, 2021(5):170-190.

[3] Zhao, L, \& Wang, K. Social Connections within Top Management Team and M\&A Performance[J]. Journal of Financial Research, 2020(11):170-187.

[4] Pang, B. Internal Control, Non-recurring Profit \& Loss and Enterprise Performance[J]. Communication of Finance and Accounting, 2020(14):57-59,68. 
[5] Xia, Y. \& Lin, Z.A. Technology M\&A and Economic Performance of Enterprises: Taking High-Tech Enterprises as an Example [J]. Communication of Finance and Accounting, 2020(6):19-22,71.

[6] Zhang, J., \& Shi, Z. Will M\&A Experience Create Value For M\&A Firms? - Multiple Missetting Bias Analysis Based on Meta [J], Guizhou Social Sciences, 2019(11): 134-144.

[7] Zhao, J.Y., \& Lu, Z.F. Does Pension Contribution Rate Affect Firm Productivity? [J], Economic Research Journal, 2018(10):97-112.

[8] Zhu, Y., \& Wang, G. Does the Technical Executives Power Has a Greater Influence on the Firm Performance than the Non-technical Executives Power? --Empirical Evidence from Chinese A-share Listed High-tech Firms [J]. Accounting Research, 2017(12): 73-79\&97.

[9] Wu, H.H., Liu, X.B., \& Ji, Y.B. How Do Tax Cuts Affect Firm Business Efficiency? --Based on the Quasi-natural Experiment of Western Development Policy [J]. Journal of Finance and Economics, 2017 (4): 55-67.

[10] Zuo, X., \& Li, H.W. Community Networks in the Labor Market and Enterprises' Productivity in the Marketization Process [J]. Economic Research Journal, 2017(3): 106-121.

[11] Zhang, C, \& Yu, P.Y. Will Different Types of M\&A Affect the Performance of Chinese Enterprises after Technological M\&A [J], Science \& Technology Progress and Policy, 2017(7): 76-81.

[12] Chen, L.M., \& Wang, X.X. Influencing Factors of Chinese Firms' Merger \& Acquisition Performance: An Empirical Study Based on The Resource-based View and Institution-based View [J], Journal of Zhejiang University (Humanities and Social Science), 2016(6): 162-174.

[13] Wu, C.P., Wu, S.N., \& Zheng, F.B. A Theoretical and Empirical Study on Manager's Behavior and Performance of Serial Acquisitions [J], Management World, 2008(7):126-133,188.

[14] Hsieh C-T, Zheng S. Grasp the large, let go of the small: The transformation of the state sector in China[R]. NBER Working Paper, 2015. 